Socialist Studies / Études socialistes 8 (1) Winter 2012

Copyright ๑ 2012 The Author(s)

Article

\title{
G.A. COHEN AND THE LOGIC OF EGALITARIAN CONGRUENCE
}

\author{
DAVID RONDEL \\ Department of Philosophy, Ryerson University. Toronto, Canada. ${ }^{1}$
}

\begin{abstract}
In this article, I argue that G. A. Cohen's defense of the feminist slogan, "The personal is political", his argument against Rawls's restriction of principles of justice to the basic structure of society, depends for its intelligibility on the ability to distinguish-with reasonable but perhaps not perfect precisionbetween those situations in which what Nancy Rosenblum has called "the logic of congruence" is validly invoked and those in which it is not. More importantly, I will be suggesting that the philosophical shape of Cohen's critique makes it difficult for him to supply the required criterion, and that the methodological "intuitionism" he claims to be committed to is at odds with his larger argument against Rawls concerning the subject of justice.
\end{abstract}

\section{Résumé}

Dans cet article, je maintiens que la défense par G.A. Cohen du slogan féministe 'ce qui est personnel est politique', son argument contre la restriction des principes de justice de Rawls à la structure basique de société, dépend pour son intelligibilité de la capacité à distinguer - avec une précision raisonnable mais peut-être pas parfaite - entre ces situations où ce que Nancy Rosenblum a appelé 'la logique de congruence' est invoquée avec validité et celles où elle ne l'est pas. Plus fondamentalement, je suggère que la forme philosophique de la critique de Cohen ne lui permet pas de fournir le critère de distinction approprié et que l' "intuitionnisme » méthodologique auquel il se dit

\footnotetext{
${ }^{1}$ David Rondel is visiting assistant professor of philosophy at Ryerson University. He was previously visiting assistant professor at Trent University, during which time he taught courses in moral and political philosophy. He works mainly in political philosophy and ethics, and has had work appear in (among others) the Journal of Philosophical Research, Journal of Speculative Philosophy, Philosophy \& Rhetoric, and the South African Journal of Philosophy. He may be reached at davidrondel@yahoo.com
}

David Rondel est professeur assistant de philosophie invité à Ryerson University. Avant, il était professeur assistant invité à Trent University, où il enseignait la philosophie morale et politique. Il étudie surtout la philosophie politique et l'éthique et ses travaux sont parus dans les revues suivantes, entres autres: Journal of Philosophical Research, Journal of Speculative Philosophy, Philosophy \& Rhetoric, et South African Journal of Philosophy. Il peut être joint à davidrondel@yahoo.com. 
fidèle est en contradiction avec son argument général contre Rawls au sujet de la justice.

\section{Keywords}

distributive justice; G.A. Cohen; intuitionism; John Rawls; subject of justice

\section{Mots-clés}

G.A. Cohen; intuitionnisme; John Rawls; justice distributive; sujet de justice

"The principles of justice for institutions must not be confused with the principles which apply to individuals and their actions in particular circumstances. These two kinds of principles apply to different subjects and must be discussed separately.”

\section{- John Rawls, A Theory of Justice}

According to John Rawls, and to liberals more generally, social justice and personal morality answer to different principles. Principles of justice that preside over what Rawls has famously called "the basic structure of society" are not the same as the normative principles that govern individual moral conduct. This does not mean that it is a category mistake to say that individuals may sometimes conduct themselves unjustly; only that locutions like "immoral but not unjust," or "unjust but morally tolerable" are not contradictory or unintelligible. ${ }^{2}$ The liberal Rawlsian view is simply that there is a crucial distinction between (a) what we owe to each other collectively, through the social and political institutions that represent us and sometimes act in our name, and (b) what we owe to each other individually, as discrete men and women.

Here we find that quintessentially liberal idea: a "moral division of labor". A division of labor of this sort will seem plausible, one suspects, for anyone who agrees with Rawls that, "...the correct regulative principle for anything depends on the nature of that thing" (Rawls 1971, 29). The correct principles for social institutions are different from the correct principles for individuals, then, in virtue of the banal truth that social institutions and persons have different natures. Unlike social institutions, men and women routinely seek the warm ties of loyalty, love, solidarity, and affection; they engage in projects of self-creation; they are capable of being inflamed, disgusted, alienated,

\footnotetext{
${ }^{2}$ As Rawls pointed out, "Many different kinds of things are said to be just and unjust: not only laws, institutions, and social systems, but also particular actions of many kinds, including decisions, judgments, and imputations. We also call the attitudes and dispositions of persons, and persons themselves, just and unjust. Our topic, however, is that of social justice. For us the primary subject of justice is the basic structure of society, or more exactly, the way in which the major social institutions distribute fundamental rights and duties and determine the division of advantages from social cooperation." (Rawls 1971, 7)
} 
invigorated; they can suffer from psychic sickness, akrasia, depression, and much more too. Principles of personal morality, Rawls has it, precisely because they depend on the unique nature of persons, differ from the principles of justice that apply to the basic social institutions of a society. ${ }^{3}$

G.A. Cohen has powerfully and elegantly argued against one instantiation of this Rawlsian division of labor, suggesting that Rawls's restriction of principles of distributive justice to the basic structure of society (but not the personal choices of citizens made within that structure) turns out to be "morally incoherent". If distributive justice consists in giving each person her due, and if some principle is indeed a correct principle of distributive justice, then, Cohen has it, "there is no good reason why the very principles that govern the basic structure should not extend to individual choice within that structure" (Cohen 2008, 359). Cohen does not say that the complete set of normative principles for social institutions is identical with the complete set of normative principles for private citizens. His claim is the more modest one that principles of justice apply, even if other sorts of principles do not, both to the basic structure and - "in appropriately different fashion" (Cohen 2008, 10) - to personal choices made within the structure.

At the heart of Cohen's argument against Rawls is a transposition from institutions to citizens, from politics to persons. It involves a particular form of what I shall call, borrowing a phrase from Nancy Rosenblum (1994), "the logic of congruence". Rosenblum herself introduced that phrase to identify and criticize a view according to which civic associations within a democracy must themselves be internally democratic, but readers should be able to see that the same "logic" - the same extension or transfer of normative principles from the purview of one subject (the basic structure) to another

\footnotetext{
${ }^{3}$ Or, as Thomas Nagel well summed up the idea: “Institutions, unlike individuals, don't have their own lives to lead." (Nagel 1991, 59)

${ }^{4}$ This is close to the view that Liam Murphy (1998) calls "monism", which says that no distinction can be drawn between the institutional and the personal where fundamental normative principles are concerned. If such fundamental principles apply anywhere (i.e. the basic structure) they therefore apply everywhere (i.e. personal choices within the structure). Murphyan monism is a view about which Cohen claims, surprisingly, to "have no definite view". (Cohen 2008, 397) Whatever the differences between Murphyan monism and Cohen's view - and there are certainly subtle differences between them - it seems clear that Cohen's position cannot be understood as a wholly negative, anti-dualist one. While Cohen does insist that his "ambitions are not general in this domain," (Cohen 2008, 398), he does suggest, more affirmatively, that "principles of distributive justice, principles, that is, about the just distribution of benefits and burdens in society, apply, wherever else they do, to people's legally unconstrained choices. Those principles, so I claim, apply to the choices that people make within the legally coercive structures to which, so everyone would agree, principles of justice (also) apply." (Cohen 2008, 116) Thus, we can safely assume that on Cohen's final, considered view, principles of distributive justice always bear on individual choices and never only bear on the basic structure. This sounds like a brand of monism to me, but even if it is not, the logic of congruence I am labeling Cohen with is intended to be something stronger and more affirmative than a merely negative anti-dualism. See Pogge 2000 for a valuable discussion of these issues.
} 
(individual citizens) - is the decisive issue in the dispute between Cohen and Rawlsian liberals.

The logic of congruence stands in nearly perfect contrast to the logic of a division of labor. Whereas division of labor arguments claim that two things are rather different and need to be assessed by different principles — viz., Rawls's argument about institutions and persons ${ }^{5}$ — congruence arguments claim that two things, while perhaps different, should nevertheless be assessed by the same principles. It is worth recalling here that the strict moral congruence at its centre was precisely the aspect of utilitarianism to which Rawls in A Theory of Justice most strongly objected. Utilitarianism rejects the very possibility of a moral division of labor between institutions and persons: it puts forward a single, all-encompassing moral principle, a principle intended to apply without qualification to all moral subjects — individuals and societies alike.

It is also important to notice that both congruence and division of labor arguments bear on the question concerning the proper subject of principles, not the merits or demerits of the principles themselves. The question is not: What are the correct principles? but rather: To whom or what do the correct principles, whatever they are, apply? Just as Rosenblum's opponents make the state and civic associations "congruent" by insisting that both be bound by the same democratic principle(s), Cohen insists on the congruence between institutions and persons insofar as adherence to principles of distributive justice is duly (though differently) required of both. Cohen's "congruence" is not perfect, however, since he grants individuals the prerogative to depart from unqualified adherence to principles of justice in their personal lives (within reasonable but admittedly vague limits). ${ }^{6}$ As he says, "The prerogative grants each person the right to be something other than an engine for the welfare of other people: we are not nothing but slaves to social justice." (Cohen 2008, 10) This important concession notwithstanding, it remains the case that Rawls supports a division of labor between the basic structure and individual citizens vis à vis distributive justice, and Cohen counter-supports a congruence between them. The two sides of the dispute are easily spotted in what Kwame Anthony Appiah has to say in his own brief discussion on the matter:

Liberalism, in most accounts, is indeed concerned with moral equality: the state is to display equal respect towards its citizens. Where we go wrong is to suppose that individuals should be subject to the same constraint. Social justice may require impartiality - or evenhandedness, or fairness, or

\footnotetext{
${ }^{5}$ See this essay's epigraph.

${ }^{6}$ In line with what Samuel Scheffler (1982) has called “agent-centered prerogatives". More recently, David Estlund (1998) has argued in favor of widening the scope of the prerogative for reasons deriving from ties of loyalty, love, and affection. Cohen addresses Estlund's argument in the appendix of Rescuing Justice and Equality.
} 
(under some construction) 'neutrality'. But social justice is not an attribute of individuals. An individual can no more be required to be impartial among his fellow creatures than he can be obligated to administer his own currency system. Here we find the 'logic of congruence' at its most grotesque. (Appiah 2005, 228)

In this paper, I want to consider the "congruence" question in the form which I regard as most germane to the dispute between Cohen and Rawls about the subject of justice: When can a moral duty legitimately be extended or transferred to someone else in those cases when, for whatever reason, an institution or person fails to meet the duty that is properly theirs?

I take it as obvious that there are duties that are rightly transferred in some situations and erroneously transferred in others, thus disqualifying "always" and "never" as candidate answers to my italisized question. The proviso "in those cases when, for whatever reason, an institution or person fails to meet the duty that is properly theirs" is crucial for Cohen's side of the argument. For it is one thing to say, as liberals characteristically do, that it is the responsibility of the state to deliver distributive justice, and another thing entirely to claim that no analogous distributive duty falls on individual citizens when the state does not meet that responsibility. ${ }^{7}$

It will be my argument in this paper that Cohen's general defense of the feminist slogan, "the personal is political", his claim against Rawls that principles of justice apply both to institutions and persons, depends for its intelligibility on the ability to distinguish - with reasonable but perhaps not perfect precision - between those situations in which the logic of congruence is validly invoked and those in which it is not. Put another way, I will be arguing that, in order for his argument against Rawls to succeed, Cohen must tell us something general about when and under what kinds of circumstances duties may be validly extended or transferred. More importantly, I will be suggesting that the philosophical shape of Cohen's critique and the so-called "radical pluralism" to which he claims he is committed makes it difficult for him to supply what I claim he must. While I do not argue that this argument wholly vindicates Rawlsian liberals from Cohen's

\footnotetext{
${ }^{7}$ It is important to note here the close relationship between questions about congruence and questions about transfers or extensions of duty. If individuals and institutions are made congruent with respect to some principle, then it follows as a matter of course that individuals will sometimes be on the hook, so to speak, for certain transfers or extensions of duty. Plainly put, if Citizen $Q$ and Institution $L$ are bound by the same normative principle, $\mathrm{p}$, then Citizen $Q$ will sometimes have an obligation to do what $\mathrm{p}$ requires, at minimum, if and when Institution $L$ fails to. Hence, the transfer or extension of duty question follows from and depends on the congruence question. For all legitimate transfers or extensions of duty, the logic of congruence has been invoked backstage. Where there is a legitimate transfer or extension of duty, the duty receiver has necessarily been made "congruent" with the duty dispenser as it concerns some normative principle.
} 
challenge, it does, as I will try to demonstrate only briefly towards the end of the paper, provide some powerful reasons for following Rawls in regarding "the basic structure of society" as the primary subject of social justice.

Let me begin with a preliminary comment about some curious methodological remarks that Cohen makes in the introduction to Rescuing Justice and Equality. Cohen there tells us that he is an adherent of the conception of moral and political philosophy that John Rawls in A Theory of Justice identified as "intuitionism" — a conception which Cohen himself prefers to call "radical pluralism". ${ }^{8}$ According to this view (supposedly more popular among "Oxford types" than "Harvard types"), "we determine the principles that we are willing to endorse through an investigation of our individual normative judgments on particular cases, and while we allow that principles that are extensively supported by a wide range of individual judgments can override outlier judgments that contradict those principles, individual judgments retain a certain sovereignty." (Cohen 2008, 4) For intuitionists, a certain fuzziness or vagueness about our moral responsibilities is unavoidable. They believe that there is no precise, general answer to questions like: "How do you decide when to struggle against injustice and when to devote yourself to private projects and self-creation?" or "What percentage of my time and effort should be devoted to increasing the sum of human happiness and what percentage to my personal hobbies?" As Richard Rorty suggests, such questions are just as hopeless as the question, "Is it right to deliver $n$ innocents over to be tortured to save the lives of $m \times n$ other innocents?" If so, what are the correct values of $n$ and $m$ ?" (Rorty 1989, xv) Cohen and Rorty agree that there are no deep algorithms for resolving moral dilemmas of this kind. They agree that "unstructured trade-offs", "intuitive balancing", and a "mass of normative requirements that we negotiate without method or compass" are our fate. (Cohen 2008, 5) In dealing with questions about the scope and content of our moral responsibilities, they agree that, "we are simply to strike a balance by intuition, by what seems to us most nearly right." (Rawls 1971, 34)

I happen to be sympathetic with this "intuitionist" methodological picture, which is only to say that I agree with Cohen that the moral precision and neatness sought by non-intuitionists simply isn't in the cards (it is not to express a sympathy for the "Trolley Car" brand of ethical reflection endemic among intuitionists of a certain stripe). Yet it is difficult to recognize Cohen the self-professed "intuitionist" in much of what is written in Rescuing Justice and Equality and elsewhere. It is unclear, more particularly, whether an intuitionist of Cohen's ilk would be permitted to argue in precisely the manner Cohen is

\footnotetext{
${ }^{8}$ That Cohen prefers to call this view "radical pluralism" is slightly misleading in my opinion since it folds into Rawlsian "intuitionism" a view along the lines of (Berlinian) value pluralism. Such folding is explicitly objected to by Rawls, who says that, "a conception of justice can be pluralistic without requiring us to weigh its principles by intuition." (Rawls 1971, 35) Intuitionism is principally about method for Rawls, and needn't require any further theses about the nature of value.
} 
wont to argue: to pronounce unequivocally (in general and at the level of theory, as it were) that "the personal is the political," that principles of justice must apply to the basic structure as well as legally unrestrained personal choices within the structure. Wouldn't the more responsible intuitionist path involve examining individual cases, and, following the advice of Frances Kamm (of whose "standard deontology" Cohen enlists himself a member), trying to uncover rules by way of "intuitive judgments about many cases"? (Kamm 2002, 337) If, as intuitionists believe, "individual judgments [about particular moral cases] retain a certain sovereignty," (Cohen 2008, 4) then the appropriate intuitionist response to the question "Is the personal political?" should never be a simple "yes" or "no". It should rather be something like, "Well, it depends on the context. Tell me more about the particular situation you have in mind and I'll tell you what my hunch is." The two examples I introduce and discuss below are offered in the spirit of this "more responsible intuitionist path". 9

\section{Duties in a Just Society and Duties in an Unjust Society}

Liberal egalitarians typically believe that individuals ought to be excused from bearing the distributive burdens that legitimately belong to the state. Here again is our old friend, a moral division of labor. The argument for such a division of labor is commonly made on the basis of Rawls's distinction between "two kinds of moral powers", and the division of standpoints in each of us that accompanies it. ${ }^{10}$ Commitments that spring from "our capacity for a sense of justice" need not generate identical commitments with respect to "our capacity for a conception of the good" (beyond our personal choices about whether or not to promote, support, and comply

\footnotetext{
${ }^{9}$ Cohen seems committed to this vague, case-by-case kind of approach when questions about the scope and limits of the one's personal prerogative (to depart from strict adherence to principles of justice in our private lives) arise. There is no algorithmic precision to be had here, he thinks, and I am tempted to agree. Notice, however, that the very existence of a Cohenian personal prerogative already means that principles of justice bear on private choices. The prerogative just tells us how much or how far they bear. If the existence of the prerogative means that, "we are not nothing but slaves to social justice" (Cohen 2008, 10, my emphasis), then that surely means that, on Cohen's view, we are also slaves to social justice — it just turns out, so the prerogative reminds us, that that's not all we are.

${ }^{10}$ See Rawls 1971, 505-510 and Rawls 2001, 18-24. The distinction drawn by Ronald Dworkin between personal preferences and external preferences is also relevant. The former has to do with one's "own enjoyment of some goods or opportunities," the latter with "the assignment of goods and opportunities to others" (Dworkin 1977, 234). A similar idea lies at the heart of Richard Rorty's (1989) view that private projects of self-creation need not be consolidated philosophically with the public, liberal project of reducing suffering and cruelty. Rorty's "liberal ironist" is committed to making her private life beautiful and her public life humane; she is ready to admit, however, that these two commitments may have little or nothing to do with each other. It is essential to all such liberal views that human beings have the capacity to separate - even if only provisionally and temporarily — questions that arise about their own conceptions of a good life from questions that arise about just social and political arrangements.
} 
with the rules of a just political order). ${ }^{11}$ I may think, for example, that elderly citizens ought to be entitled to a certain modicum of state-sponsored care. I may be passionate about the issue, regarding the distribution of such care as a fundamental imperative of justice (as incidentally I do). But it does not follow that $I$, in my capacity as individual citizen, have a corresponding duty to provide such care personally. In a discussion of care for the elderly, Michael Ignatieff eloquently brings this liberal conclusion into focus.

As we stand together in line at the post office, while they cash their pension cheques, some tiny portion of my income is transferred into their pockets through the numberless capillaries of the state. The mediated quality of our relationship seems necessary to both of us. They are dependant on the state, not upon me, and we are both glad of it...In my name a social worker climbs the stairs to their rooms and makes sure they are as warm and as clean as they can be persuaded to be. When they get too old to go out, a volunteer will bring them a hot meal, make up their beds, and if the volunteer is a compassionate person, listen to their whispering streams of memory. When they can't go on, an ambulance will take them to the hospital, and when they die, a nurse will be there to listen to the ebbing of their breath. It is this solidarity among strangers, this transformation through the division of labour of needs into rights and rights into care that gives us whatever fragile basis we have for saying that we live in a moral community. (Ignatieff 1984, 9-10; quoted in Waldron 1993, 382. Emphasis added.)

Our community is "moral" not because it is comprised of a collection of discrete individuals, each of whom can be counted on to act as morality requires. It is instead a community built upon our capacity for a conception of justice, a conception according to which, as Cohen glosses it, "some aims which are rightly pursued by government...are not aims that citizens themselves can and/or should be expected to pursue (apart from the pursuit of them in which citizens engage when they support those aims politically)." (Cohen 2000, 148) "[T]he demands placed by justice on government do not belong on the backs of individuals, as such;" Cohen continues, "individuals discharge those demands collectively, through the government that represents them."(Cohen 2000, 148)

And yet, however attractive the liberal ideal sketched by Ignatieff might be thought to be, what if the government failed to meet the demands placed on it by justice? Would a personal duty to provide care for the elderly then fall on individual doctors, nurses (and others involved in providing care for the aged)? It isn't necessary to speculate

\footnotetext{
${ }^{11}$ In a similar vein, T.M. Scanlon distinguishes between "principles of justice" and "principles of individual conduct". (Scanlon 1998, 228)
} 
on the right answer to this question, but readers might wish to consider whether they would be satisfied with the reply "But it's not my job. It falls to the state to take care of old people" coming from individual nurses or physicians who denied any such personal duty. One need not endorse a view like Shelly Kagan's (1989), according to which morality obliges us to make the world as good as possible, in order to agree with Cohen that a reply along these lines is morally indefensible.

Cohen thinks that Rawlsian liberals find themselves in a similar predicament: they are at once committed to principles (of justice) as a requirement of justice in institutional design, but indifferent to those very principles as a requirement of personal morality even when the distributive justice they endorse for institutions does not obtain. ${ }^{12}$ Liberals who exclude personal behavior from what Cohen (1997) calls "the site of distributive justice" thus demonstrate an insensitivity to the important point that,

[T] he question 'What does justice demand of individuals in a just society?' is not the same as the question 'What does justice demand of individuals in an unjust society?'...I ask whether egalitarians who live in an unequal society (one...whose government...fails to enforce, and will continue to fail to enforce, whatever equality it is that these egalitarians favor) are committed to implementing, so far as they can, in their own lives, the norm of equality they prescribe for government. ${ }^{13}$ (Cohen 2000,149 )

This is a profound challenge for Rawlsian liberals, and I will come back to it in a moment. It will be enough to note here that Cohen's argument for an egalitarian ethos in personal choices does not wholly depend on whether or not a society's basic structure is just. Cohen's argument is that justice demands an egalitarian personal ethos both of citizens living in a society with a just basic structure, and - equally, though more urgently to be sure - of citizens living in a society without a just basic structure.

\footnotetext{
${ }^{12}$ Cohen critisizes Dworkin's "equality of resources" on exactly this score: "Within Dworkin's theory of equality, the locus of the norm of equality proper...is the relationship between the state and those whom it claims the right to govern. Because it claims that right, the state must treat its citizens with equal respect and concern, on pain of being a tyranny, and it must therefore distribute resources equally to its members. But if the state fails to do so, then no analogous duty falls on individuals. It is not the individual's duty to treat everyone (relatives, friends, and strangers alike) with equal respect and concern." (Cohen 2000, 164. Emphasis added)

${ }^{13}$ In failing to implement in their own lives the norm of equality they prescribe for government, it is important to distinguish between individual behavior which: (a) runs contrary to the egalitarian norm, and (b) (merely) isn't motivated by the egalitarian norm. After all, the fact that I am committed to principle X doesn't mean I must always and only act from a sense of X.
} 


\section{"But it's not my Job"}

The general question put before us by Cohen, then, is the following: When does a personal duty to do $X$ follow from someone else's failure to do X? Taking the intuitionism Cohen claims he is committed to seriously, let us consider two different cases:

(a) The Case of the Lifeguard and the Drowning Person (Paraphrasing Cohen): "If it's the lifeguard's duty to save the drowning person, and the lifeguard isn't doing it, and I can swim to save that person, it's not an acceptable answer to the question 'Why didn't you save him?' to say 'It was someone else's duty"' 14

(b) The Case of the Attendant and the Public Washroom. If it's the attendant's duty to keep the toilets in the public park clean, and he or she isn't doing it, and I can easily spend a few minutes cleaning up (a mop and other supplies, let us say, are sitting in plain view), it is an acceptable answer to the question 'Why didn't you tidy up?' to say 'It was someone else's duty'.

These two cases are not offered in the spirit of a reductio ad absurdum. On the contrary, I think Cohen is perfectly correct about The Lifeguard Case. I simply want to claim (I hope uneccentrically) that the logic of congruence applies in the first case but not in the second. Or, put another way, whereas the lifeguard's duty is legitimately extended to me in (a); the attendant's is not in (b). How shall we account for this?

Following the intuitionist's creed that "we must strike a balance by what seems to us most nearly right" allow me to submit that the valid extension of duty in the lifeguard case is distinguished from the invalid extension of duty in the attendant case by the boring truism that death by drowning is far more serious, morally speaking, than the momentary unpleasantness of a neglected washroom. It is in the end the moral seriousness of The Lifeguard Case that sets it apart from the moral innocuousness of The Bathroom Attendant Case. There are many different ways to make this point, I suspect and many details over which to fuss - but allow me to use the phrase "moral seriousness" as shorthand for whatever it is that makes these cases different; whatever it is precisely that extends to us a duty in the one case, and fails to do so in the other.

The conclusion that moral seriousness holds the key to distinguishing between the valid and invalid transfers of duty in our two cases is by no means without consequence for Cohen. If that conclusion is on the mark, it turns out that Cohen's question - "What

\footnotetext{
${ }^{14}$ This is Cohen's own example. I paraphrase his words from a short interview he gave with Philosophy bytes.
} 
does justice demand of individuals in a society with a just basic structure?" - depends in part for its answer on the further questions: "How dire is the situation?", "How badly off do those at the bottom of society happen to be"?, "How much inequality is there?", "How morally serious is it?" and so on. If valid transfers of duty are distinguished from their invalid counterparts in virtue of their more acute moral seriousness, then Cohen's argument that principles of distributive justice should bear on people's personal choices is lacking an important premise, viz., the premise that principles of justice, when applied in limited Rawlsian fashion to the basic structure alone, would result in levels of inequality that were sufficiently "morally serious" so as to warrant an extension of duty to individual citizens. It is difficult to see how Cohen could object to the insertion of this premise into his argument. After all, if he was willing to concede that justice demands different things of people living in just and unjust societies - roughly, that we are called upon personally to be more thoroughgoing egalitarians where and when there is more inequality - hasn't he already conceded, in virtue of the first concession, that our duties exist on a continuum, that they shift according to context, that they change with circumstances? Unfortunately, no such premise figures in the official version of Cohen's argument against Rawls. On the contrary - and it is here in particular that he seems to betray the "intuitionism" or "radical pluralism" to which he claims he is committed - Cohen is emphatic that his argument does not depend on the (possibly) rather small range of inequality that might obtain if, as Rawls envisioned, principles of justice were restricted to the basic structure only. Any argument to that effect, we are assured, doesn't touch the philosophical point that Cohen is making.

My central criticism of Rawls is within political philosophy, not within public policy: it is not the heart of my contention that a society that is just by Rawls's lights exhibits too much inequality, although I indeed believe that... But what I centrally reject is a certain justification for inequality, a certain representation of the conditions under which it is just. I reject that justification regardless of how much inequality it would actually justify, or might be thought by Rawls to justify...To the extent that mine is a critique of a justification, it is no objection to that critique to say, as a number of my critics have said, that the amount of inequality that the Rawlsian justification of it would justify is for various reasons not great...It is no answer whatever to 'This justification of inequality doesn't work' to say 'Oh, well, that shouldn't worry you too much, since the justification won't justify too much inequality anyway. Other things are helping to take care of that.'...Philosophy is interested in grounds, not ranges, of inequality. (Cohen 2008, 382-383) 
Yet if we suppose, as several commentators have, that a society organized in accordance with Rawlsian principles of justice would in fact have very little inequality, should that not to some extent influence where on the continuum of moral seriousness, as it were, Cohen's call for an extension of principles of justice was rightly placed ${ }^{15}$ Might we not in that case ask Cohen to explain why extending principles of distributive justice to people's private choices wasn't more akin to the Bathroom Attendant case than the Lifeguard case with respect to moral seriousness? In short, if Cohen is interested in grounds not ranges of inequality, then he must offer us a principled criterion, a ground one which does not make use of "moral seriousness," or some other relevantly similar notion - to distinguish between the valid transfer of duty in the Lifeguard case and the invalid transfer of duty in the Attendant case. If it is true, as I have been urging, that the logic of congruence is properly invoked in some situations but improperly invoked in others, Cohen must show that the transfer (or extension) of duty at the heart of his argument against Rawlsian liberals is indeed one for which the logic of congruence is properly invoked. My argument, in short, has been that this conclusion cannot be demonstrated in abstraction from judgments about the moral seriousness of the inequality that prevails when principles of justice are applied in Rawlsian fashion to the basic structure alone, but also that Cohen explicitly deems any such judgments, philosophically speaking, out of bounds.

\section{On the Attractiveness of Rawlsian Justice}

I confess to having no idea how to answer the general "congruence" question at the level of theory, without recourse to the details of a particular moral situation in which questions of duty-transfer arise. It is not clear that Cohen knows either (indeed, it might be thought definitive of his "radical pluralism" that no such answers can be given here).

Such murkiness about the scope and content of our moral duties in various circumstances only underscores, I believe, the overall attractiveness of Rawls's conception of justice. By restricting the ambit of justice to "the basic structure of society" Rawls has effectively made complex (intractable?) puzzles about our moral duties in specific cases irrelevant to the appraisal of a society as just. "[P]art of the reason why Rawls thinks that

\footnotetext{
${ }^{15}$ I do not argue here that a society that is just by Rawls's lights would in fact have very little inequality. Nobody really knows with any certainty how a Rawlsian society would actually be like, given among other things that there has never been anything like such a society. I am only interested in the conditional claim that if the inequality that prevailed in such a society was minimal and not acutely morally serious, then that should have some bearing on the dispute between Rawls's division of labor position and Cohen's "congruence" counter-position. Cohen, however, denies that that conditional has any such bearing whatsoever - even if the (Rawls permitted) inequality was minimal, Cohen would still disapprove of it on the grounds that it was not adequately justified — and I am suggesting that he is mistaken to look at things in this way.
} 
we should focus on the basic structure of society," Christine Korsgaard rightly points out, "is that this way we can avoid having to make moralizing judgments about individual cases." (Korsgaard 1993, 61) This doesn't mean that such moral questions don't matter — that making moralizing judgments about individual cases is always and everywhere a bad thing to do. Nor does it mean that we should simply declare that no precise answers can be given on the subject and move on to more pressing matters, though that too, certainly, is one kind of possible response. It merely suggests that it needn't be a theory of justice whose task it is to answer questions about our moral responsibilities in particular cases. It is not defeatist to say that such questions can be addressed by other theories. It pays to remember that justice is not the only consideration that bears on the question, "What ought to be done?" Labeling something "unjust" is not the only way in which to disapprove of it. A theory of justice can be silent about our moral responsibilities in specific cases - as Rawls's theory surely is - and remain none the worse as a theory of justice for that.

Rawls's is a conception of justice fit for modernity's disenchanted universe, accentuating that justice has nothing to do with "cosmic fairness" - with how the universe or its inhabitants might have otherwise been - nor with the wrath of an invisible deity. Contrary to what Plato may have held, it also disqualifies human souls as rightful bearers of the designation "just". ${ }^{16}$ As Rawls himself may have expressed it, restricting the subject of justice to "the basic structure" helps us see justice as "political, not metaphysical". I agree with Brian Barry, moreover, when he points out (in a passage cited by Cohen in If You're and Egalitarian How Come You're So Rich?):

If Rawls had achieved nothing else, he would be important for having taken seriously the idea that the subject of justice is what he calls 'the basic structure of society.'... When we talk about the basic structure... we are concerned with the way... institutions work systematically so as to advantage some and disadvantage others. Rawls's incorporation of...a social structure into his theory represents the coming of age of liberal political philosophy. For the first time, a major figure in the broadly individualist tradition has taken account of the legacy of Marx and Weber. (Barry 1995, 214)

Like Marx and Weber - and we might also mention their Frankfurt School heirs Rawls was concerned about injustice built into the system as it were, and not simply with individual men and women who might sometimes act in unjust ways.

\footnotetext{
${ }^{16}$ I don't mean to suggest, however, that on Rawls's view no sense can be attributed to talk of just and unjust souls. See footnote 1 above.
} 
It is hard to imagine Cohen having been moved by this way of thinking. He imbued the activity of philosophy with a kind of Platonic purity that is difficult to square with Rawls's efforts to "stay on the surface, philosophically speaking". Philosophical questions on Cohen's view were insulated from everything else; quarantined from other kinds of questions and concerns. The question "What is justice?" was perhaps paradigmatically a philosophical one for Cohen, and as such, could not be influenced in the slightest by any impure, non-philosophical, considerations - considerations having to with feasibility, say, or other (merely) practical matters. ${ }^{17}$ Again and again in Rescuing Justice and Equality we find Cohen affirming the purely philosophical and conceptual nature of the question "What is justice?" In point form only, consider seven examples:

(1) Rawlsian constructivism is hopelessly off the mark, Cohen argues, because it conflates the outcome of an idealized procedure - the Original Position — with the different and independent question of what justice is.

(2) Cohen rejects Elizabeth Anderson's critique of the "luck egalitarian" view of justice (cf. Anderson 1999) on the grounds that it mistakenly runs together questions of bringing about justice in the world with the philosophical question about justice's real nature. As Cohen writes: "difficulties of implementation, just as such, do not defeat luck egalitarianism as a conception of justice." (Cohen 2008, 271)

(3) Cohen rejects the view according to which feasibility (or even possibility) establishes the bounds of justice. "If justice is, as Justinian said, each person getting her due, then justice is her due irrespective of the constraints that might make it possible to give it to her."

\footnotetext{
${ }^{17}$ The details of Cohen's metaethical and metaphilosophical thinking are far too unique, numerous, and complicated to fully unpack here. However, I have been suggesting that a certain tension exists between Cohen's (self-ascribed) "Platonism" about justice — justice just is, always the same, enduring, untouched by the facts and everything else of this world - and the intuitionism (in Rawls's sense of that term) to which he is committed. The former encourages Cohen to say bold, general, non-contextual sorts of things that sit uncomfortably (which is not to say that they are conceptually incompatible) with the latter. To affirm, as Cohen does, that "the personal is the political" is to say something general, something indifferent to context and circumstance. A large part of my argument in this paper has been that a Cohen-style intuitionist should be made nervous by such general, context-indifferent pronouncements, that they should be much more comfortable examining principles contextually, on a case-by-case basis. That was the kind of point my Lifeguard and Attendant examples were designed to emphasize. When it comes to justice, however, it seems as though Cohen abandons this vague, intuitive, case-by-case approach and prefers to speak in general, context-independent ways.
} 
(Cohen 2008, 252-253) ${ }^{18}$ In fact, Cohen thinks it is "overwhelmingly intuitive" that, "facts about practicality and feasibility...do not affect the content of justice itself." (Cohen 2008, 278-279) On Cohen's view, there is nothing confused or misguided in the sentence-form, "Justice requires $\mathrm{X}$ even though bringing about $\mathrm{X}$ is impossible".

(4) Against a strong current of political-philosophical thought, Cohen maintains that justice does not imply the possibility of coercion, state or otherwise. "[W]e don't learn what justice fundamentally is by focusing on what it is permissible to coerce" (Cohen 2008, 148). Elsewhere Cohen writes, "The sentence form ' $x$ represents an injustice'... [does] not mean ' $x$ represents an injustice that ought to be rectified by the state'." Rather, it means "more elementarily, that the world is less than fully just by virtue of the presence of $x$ in it." (Cohen 2004, 4)

(5) Cohen immunizes the question, "What is justice?" from David Hume's influential ruminations on 'The circumstances of justice'. Cohen's argument is that identifying the circumstances under which questions about the achievement of justice arise does not shed light on the different question concerning what justice is.

(6) In response to Andrew Williams's (1998) "publicity argument" according to which "it should be possible to tell whether or not a principle of justice is being followed," - which is to say that it is necessary both that justice be done and be seen to be done - Cohen says, "whether or not publicity is a constraint on...social rules of regulation...it is not a constraint on what justice is." (Cohen 2008, 344)

\footnotetext{
${ }^{18}$ Ronald Dworkin has been an articulate defender of the opposite view. As he writes in response to Cohen, "[I]t is theoretically misleading, as well as pointless, to say that justice demands what even people with the best and most selfless will cannot do: that it is unjust that people who are born horribly crippled are not cured, for example, when there is no cure. Justice is relational: it is a matter of how people should treat one another, not of how the world should otherwise be...That relational view of justice encourages even those political philosophers who write at the most abstract level to focus their attention on what can actually be done, and political philosophy is most interesting as well as most valuable when that focus is secure... [when that focus is secure] we show how justice is feasible and therefore why it is all but imperative." (Dworkin 2004, 344)
} 
(7) Lastly, when Daniel Weinstock (2000) suggests that "by dropping Rawls's requirement of well-orderedness from our picture of the just society, we might be able to resist Cohen's...claim that only a society in which people choose justly can hope to be truly just," Cohen replies that Weinstock's proposal no more shows that such a society would be "truly just" than "dropping the requirement on pianos that they have keys enables us to say that there exist keyless pianos." (Cohen 2008, 173)

These are precisely the sorts of things one would expect to hear from someone with Cohen's metaphilosophical predilections - someone who, like Cohen, has "found it necessary to reach up to the pure concept of justice" (Cohen 2008, xvi). I believe that I speak for Rawls when I say that I know neither what "the pure concept of justice" is supposed to be exactly, nor what the activity of "reaching up for it" consists in. As if the correct method with which to answer the question "What is justice?" is simply to close one's eyes tightly and meditate, or as if the pure idea of justice has been out there all along, waiting patiently for the right philosopher to come along and apprehend it correctly. But we are now getting into metaphilosophical waters too deep to navigate here.

\section{Remembering Jerry Cohen}

Since this paper was originally written for the occasion of a special symposium dedicated to the life and legacy of G.A. Cohen, it seems fitting to conclude with some brief personal reflections about Cohen the man and the philosopher. Sadly, I never had the opportunity to meet Jerry (as his friends called him), but I have come to feel nevertheless - from stories I have heard about him, and mostly from his lucid, witty, brilliant writings - that I actually knew the man quite well. My impression of him may well be largely delusional, but I have a strong sense, or so I feel, about who Jerry was; what he cared about; what mattered to him; about the sorts of things he found philosophically interesting; the kinds of jokes he enjoyed, and so on. Much of this has to do with the fact that Jerry was an unusually generous autobiographical writer. Most philosophers treat biography as (at best) irrelevant to the philosophical enterprise, or (at worst) as a distraction from it. Not so for Jerry. His books and essays are crammed with personal stories and anecdotes: about his parents and their journey of immigration from Europe to Canada, his coming of age in a Yiddishkeit Communist household in Montreal; about the "genteel anti-Semitism" he experienced as a boy; about the playground politics of Morris Winchewsky school, and so much more. 
These autobiographical writings were (and are) fascinatingly moving to me. I suspect this has to do in part with the fact that Jerry and I are members of the rather smallish clan of Canadian, Jewish, Leftist political philosophers (which is only to point out that I feel a certain kinship with Jerry; it is not to suggest that I consider myself even remotely his equal within this clan). I felt, and feel, a certain sense of pride about Jerry, for I saw in him someone very much like myself: Canadian, non-religiously Jewish, on the political left, from similarly immigrant and impeccably proletarian families. And if someone like Jerry could rise to the distinguished echelons of Oxford University and the frontier of world philosophy; if someone like Jerry could find himself hobnobbing with the likes of Gilbert Ryle, Bernard Williams, and Isaiah Berlin, then surely I might stand a chance at landing a job somewhere teaching philosophy.

Jerry's untimely passing in 2009 has robbed us of one of the great political philosophers of a generation. He is unquestionably one of my favorite philosophers, though, perhaps strangely, I happen to think that he was mistaken about a great many things philosophically. (In fact, I think he was wrong more often, and about more things, than other philosophers about whom I feel simply indifferent). Some of what I believe Jerry to have been mistaken about is outlined in this paper. But those mistakes - if I am right that they are indeed mistakes - do not detract at all from the great respect and admiration I have for him. ${ }^{19}$

\section{References}

Anderson, Elizabeth. 1999. "What is the Point of Equality?" Ethics 109 (1), 287-337.

Appiah, Anthony Kwame. 2005. The Ethics of Identity. Princeton: Princeton University Press.

Barry, Brian. 1995. Justice as Impartiality. Oxford: Clarendon Press.

Cohen, G.A. 1997. "Where the Action Is: On the Site of Distributive Justice." Philosophy \& Public Affairs 26 (1), 3-30.

2000. If You're an Egalitarian, How Come You're so Rich? Cambridge: Harvard University Press.

\footnotetext{
${ }^{19}$ For helpful comments on an earlier draft of this paper and/or for interesting conversation about topics with which the paper deals I am grateful to Hugh Alcock, Nathan Brett, Pablo Gilabert, Alex Livingston, Alistair MacLeod, Colin MacLeod, Jan Narveson, Michael Neumann, Kai Nielsen, Nicholas Vrousalis, Alex Sager, Dan Shahar, and Byron Stoyles.
} 
. 2004. "Expensive Taste Rides Again." In Dworkin and his Critics, edited by Justine Burley. 3-29. Oxford: Blackwell. 2008. Rescuing Justice and Equality. Cambridge: Harvard University Press.

Cohen, Joshua. 2001. “Taking People as They Are.” Philosophy \& Public Affairs 30 (4), 363-386.

Dworkin, Ronald. 1977. Taking Rights Seriously. London: Duckworth.

. 2004. "Reply to G.A. Cohen." In Dworkin and his Critics, edited by Justine Burley. 339-50. Oxford: Blackwell.

Estlund, David. 1998. "Liberalism, Equality, and Fraternity in Cohen's Critique of Rawls." Journal of Political Philosophy 6 (1), 99-112.

Ignatieff, Michael. 1984. The Needs of Strangers. London: Chatto \& Windus.

Kagan, Shelly. 1989. The Limits of Morality. New York: Oxford University Press.

Kamm, F.M. 2002. "Owing, Justifying, and Rejecting”. Review of What We Owe to Each Other by T.M. Scanlon. Mind 111 (442), 323-54.

Korsgaard, Christine. 1993. "Capability and Well-Being: Commentary on G.A. Cohen and Amartya Sen". In The Quality of Life, edited by M.Nussbaum and A.Sen. 54-61. New York: Oxford University Press.

Murphy, Liam. 1998. “Institutions and the Demands of Justice." Philosophy \& Public Affairs 27 (4), 251-91.

Nagel, Thomas. 1991. Equality and Partiality. Oxford: Oxford University Press. 2002. Concealment and Exposure. Oxford: Oxford University Press.

Pogge, Thomas. 1989. Realizing Rawls. Ithaca: Cornell University Press. . 2000. "On the Site of Distributive Justice: Reflections on Cohen and Murphy." Philosophy \& Public Affairs 29 (2), 137-169. 
Rawls, John. 1971. A Theory of Justice. Cambridge: Harvard University Press. . 2001. Justice as Fairness: A Restatement. Edited by E. Kelly. Cambridge: Harvard University Press.

Rorty, Richard. 1989. Contingency, Irony, and Solidarity. Cambridge: Cambridge University Press.

Rosenblum, Nancy. 1994. "Democratic Character and Community: The Logic of Congruence?" Journal of Political Philosophy 2 (1), 67-97.

Scanlon, T.M. 1998. What We Owe To Each Other. Cambridge: Harvard University Press.

Scheffler, Samuel. 1982. The Rejection of Consequentialism. Oxford: Oxford University Press.

Scheffler, Samuel. 2006. "Is the Basic Structure Basic?" In The Egalitarian Conscience: Essays in Honour of G.A. Cohen, edited by C. Sypnowich. 102-30. Oxford: Oxford University Press.

Waldron, Jeremy. 1993. Liberal Rights. Cambridge: Cambridge University Press.

Weinstock, Daniel. 2000. "Review of If You're an Egalitarian, How Come You're So Rich? By G.A. Cohen.” Philosophy in Review 20 (6), 405-407.

Williams, Andrew. 1998. "Incentives, Inequality, and Publicity." Philosophy \& Public Affairs 27 (3), 225-47. 